\title{
Design and Prototype of Electric Smart Stove
}

\author{
$1^{\text {st }}$ Sa'adilah Rosyadi \\ dept. Electrical Engineering Education \\ Universitas Negeri Yogyakarta \\ Yogyakarta, Indonesia \\ s.rosyadi@uny.ac.id
}

\author{
$2^{\text {nd }}$ Bayu Rahmat Setiadi \\ dept. Mechanical Engineering \\ Education \\ Universitas Negeri Yogyakarta \\ Yogyakarta, Indonesia \\ bayursetiadi@uny.ac.id
}

\author{
$3^{\text {rd }}$ Joko Slamet Saputro \\ dept. Electrical Engineering \\ Universitas Sebelas Maret \\ Surakarta, Indonesia \\ jssaputro89@staff.uns.ac.id
}

\begin{abstract}
The prototype of the electric smart stove is an electric stove with briquette fuel from teak leaf waste. The thermoelectric module used is 12 units of a Peltier TEC-12706. Thermoelectric generators take advantage of the Seebeck effect with temperature differences from both sides of the Peltier will produce electrical energy. The developing prototype method of an electric smart stove is carried out in 4 stages. First stage, analyzing geometry requirements and smart stove shape. Second stage is the process making of an electric smart stove. Third stage, installation of a power plant. The fourth stage, measurement of electrical power output. Based on the experiment, it is found that the thermoelectric generator produces 1.31 volts of electrical energy with a delta $T$ of 40 degrees Celsius. As the result, an electric smart stove has not been able to charge the battery because the electric energy produced tends to be small.
\end{abstract}

Keywords - smart stove, thermoelectric generator, electrical energy

\section{INTRODUCTION}

The need for electrical energy from year to year has increased along with the increasing economic growth and human population [1]. The fulfillment of electrical energy still relies on electricity generation with raw materials from fossil and crude oil. Meanwhile, fossil raw materials and crude oil are limited and one day they will run out [2]. This encourages research on alternative energy.

The alternative energy to produce electrical energy is a thermoelectric generator [3]. A thermoelectric generator is an electrical energy generator that is based on the Seebeck effect. The series of Seebeck effects is to connect copper and iron in a strand, between the two metals a compass needle is placed. When one side of the metal is heated, the compass needle moves. This proves that between the two metals there is a magnetic field that has the potential to generate electric power. This phenomenon is known as the Seebeck effect.

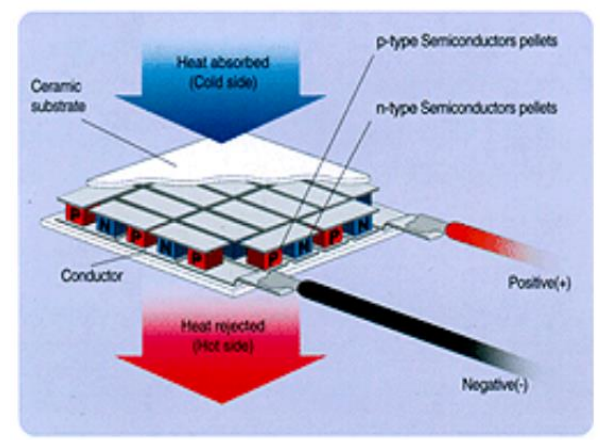

Fig 1. Thermoelectric generator with Seebeck effect

\section{(https://inbthermoelectric.com/peltier-seebeck/)}

Transfer of heat from one substance to another often occurs in industrial processes. When heat transfer takes place, it requires the inclusion or expenditure of heat energy to achieve and maintain the required state. heat transfer can be defined as the transfer of energy due to a temperature difference between one surface and the surrounding environment. Heat transfer occurs in three ways, namely induction, convection, and radiation [4]. The placement of the thermoelectric on the stove and take advantage of the heat transfer properties generated from the stove can be used to generate electric power [5].

This project aims to design a prototype of an electric smart stove as a power plant. The prototype of an electric smart stove utilizes the heat energy produced by the stove then converted into electrical energy using a thermoelectric. The thermoelectric used is TEC-12706 Peltier module. Electrical energy is generated using 12 thermoelectrics arranged in series. Thermoelectric generators arranged in series produce greater electric power [6].

The benefits of this research can be used as a reference for alternative energy producers. This alternative energy is produced by converting energy from heat into electrical energy. The electrical energy generated from the thermoelectric can potentially be used for daily needs [7].

Prototype of Smart stove can be call smart because it has advantages in function. The function of the prototype of smart stove is to utilize the energy that is usually wasted on the stove. So with the use of wasted energy, the energy utilization from the prototype of smart stove becomes efficient. The energy in question is the heat energy produced from burning briquettes. Heat energy is not only used for cooking needs but also for generating electrical energy.

\section{MATERIAL AND METHODS}

This research was conducted in 4 stages. The first stage is the process of analyzing the geometric requirements and shapes of the smart stove, the second stage is the making process of a smart stove, the third stage is the power plant installation process, and the last stage is a measurement of electrical power output.

\section{A. $\quad$ Analysis of geometric requirements and smart} stove shapes

Analysis of the geometric requirements and shapes of the smart stove begins with the identification and characteristics of the materials and shapes of the smart stove to be used. The 
shape of the smart stove is limited to a cube and a cylindrical shape. The materials used are iron and aluminum plates. The shape and selection of materials are determined based on their effectiveness as a good heat conductor.

\section{B. $\quad$ Producing Prototype of electric Smart Stove}

The stage of making a smart stove is important because it is an embodiment of the design into a prototype. At this stage, we begin to assemble the smart stove materials that have been determined, both the design and the material chosen. The main focus on the smart stove assembly was on the manufacture of Thermosplate. The Thermosplate is where the thermoelectric generator is placed in the form of a TEC12706 Peltier. Thermoelectric generator functions as a converting tool from heat energy into electrical energy.

The thermoelectric generator used is 12 units. The thermoelectric generator will be placed under the thermosplate. Under the thermoelectric generator is placed a radiator which is used as a thermoelectric coolant. Parts of the thermosplate, thermoelectric generator, and radiator are combined with 6 bolts that have been added with thermal grease between the thermosplate and the thermoelectric generator.

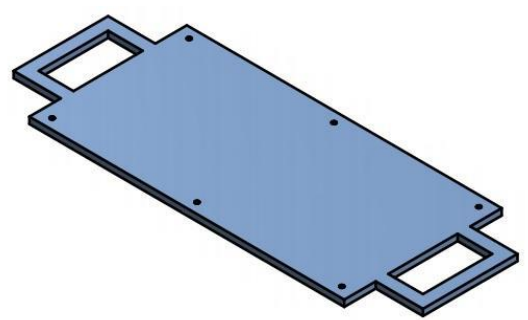

Fig 2. Thermosplate

The thermosplate is made of aluminum plate which is shaped into a rectangle. The size of the thermosplate is adjusted to the smart stove electric prototype design. The thermoelectric generator is placed in the middle of the thermosplate so that heat energy can be absorbed optimally. The dimensions of the thermosplate are $500 \mathrm{~mm}$ in length and $250 \mathrm{~mm}$ in width and are equipped with a handle for easy removal of the thermosplate holder.

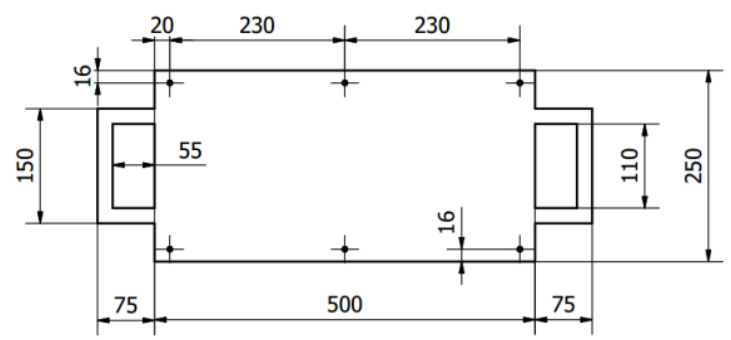

Fig 3. Thermosplate dimensions

\section{Power Plant Installation}

The power plant installation stage is the process of installing or assembling the electrical components needed to convert heat energy into electrical energy. Thermoelectric generator using peltier TEC-12706. The thermoelectric generator used in this study is 12 units. Peltier is assembled in series to get maximum output. The thermoelectric output is expected to be able to charge a battery with a capacity of 12 volts $3.5 \mathrm{Ah}$. The assumption of the thermoelectric generator output is capable of filling the battery because the thermoelectric generator is capable of producing electrical energy resulting from the temperature difference between the two sides of the thermoelectric generator. Heat energy is converted into electrical energy using the Seebeck effect found in the thermoelectric generator which can produce an output voltage of 4.17 volts from 2 thermoelectric generator units [8]. With the use of 12 units of thermoelectric generators, it is hoped that they will be able to produce electrical energy that can charge the battery. The battery charging block diagram is shown in Figure 4.

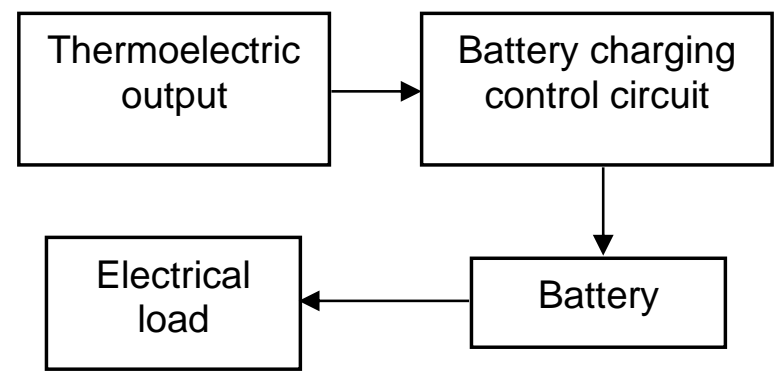

Fig 4. Battery Charging Block Diagram

The battery charge block diagram shows the battery charging system from the thermoelectric output of the generator. The electrical energy generated by the thermoelectric generator is transmitted to the battery charge control circuit. The battery charge control circuit functions to cut-off the charging circuit when the battery capacity is full. This stage wants to produce a prototype tool that is simple and can be operationalized on a household scale so that it is efficient and practical to use.

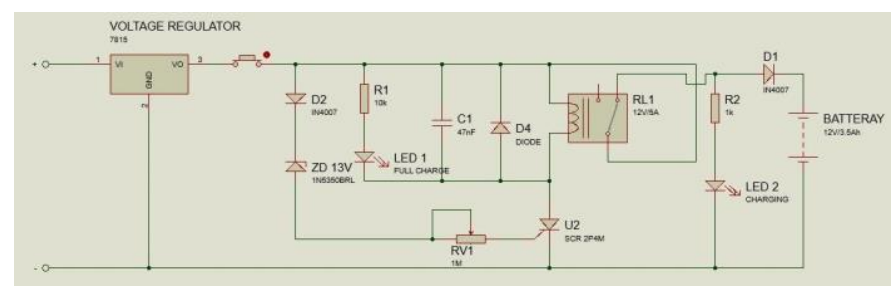

Fig 5. Battery Charging Control Circuit

Test the functionality of the battery charging control circuit is carried out using a power supply. The output power supply is 13 volts and the maximum current is 5 amperes. The battery capacity used is 12 volts $3.5 \mathrm{Ah}$. The initial voltage of the battery when it will be charged is 10.1 volts. The indicator for charging the battery used is the relationship between the battery voltage and the battery charging time. Battery voltage data collection is carried out in a span of 10 minutes. Data on the results of the battery charging control circuit functionality test is presented in Table 1.

Table 1. Data Results of Test Functionality Battery Charging Control Circuit.

\begin{tabular}{|c|c|c|}
\hline No. & Time (minute) & Battery Voltage (volt) \\
\hline 1 & 0 & 10.1 \\
\hline 2 & 10 & 10.8 \\
\hline 3 & 20 & 11 \\
\hline 4 & 30 & 11.2 \\
\hline 5 & 40 & 11.4 \\
\hline 6 & 50 & 11.5 \\
\hline 7 & 60 & 11.7 \\
\hline 8 & 70 & 11.9 \\
\hline 9 & 80 & 12.1 \\
\hline
\end{tabular}




\begin{tabular}{|c|c|c|}
\hline 10 & 90 & 12.3 \\
\hline 11 & 100 & 12.3 \\
\hline
\end{tabular}

Based on the results of the data on the functionality test of the battery charging control circuit, it is found that the charging cycle for the first 10 minutes of battery voltage has increased quite high by 0.7 volts. The next cycle increases the battery voltage around 0.2 volts. The saturation point of the battery is in the range of 12.3 volts which is obtained in the 90th minute. If the battery is in a saturated state, the battery is fully charged and the battery charging control circuit will cut the current from the power supply.

\section{Power Output Measurement}

Measurement of electrical power output using tools. The tools used are electric measuring instruments in the form of voltmeters and ammeter. The thermoelectric generator used is a Peltier TEC-12706. There are 12 Peltier units used in a series circuit. Measurements are made every 10 minutes to determine the output voltage of the thermoelectric generator. Measurement of the thermoelectric generator output voltage is carried out at the positive and negative poles of the TEC12706 Peltier series circuit. The electric energy produced depends on the number of briquettes, the design of the Thermosplate, and the quantity of the Peltier.

\section{RESULT AND DISCUSSION}

\section{A. Design prototype of an electric smart stove}

The prototype smart stove design is developed based on technical information regarding the reference and datasheet of the thermoelectric generator component. The main focus in developing this product is how to produce a high delta $\mathrm{T}$ to produce a high electrical energy output. To produce maximum delta $\mathrm{T}$, the hot side of the Peltier TEC-12706 requires more heat and cools the reverse side.

The heat side of TEC-12706 Peltier is heated from the smart stove. The heat generated is then funneled through the Thermosplate. The Thermosplate has 12 unit Peltiers. The Thermosplate is placed at the bottom of an electric smart stove. This placement aims to allow the heat to flow optimally.

The cool side of the TEC-12706 Peltier is cooled using a heatsink made of aluminum. The heatsink is immersed in a colling tank filled with coolant liquid. It moves downwards in a waterfall method that passes through the radiator.

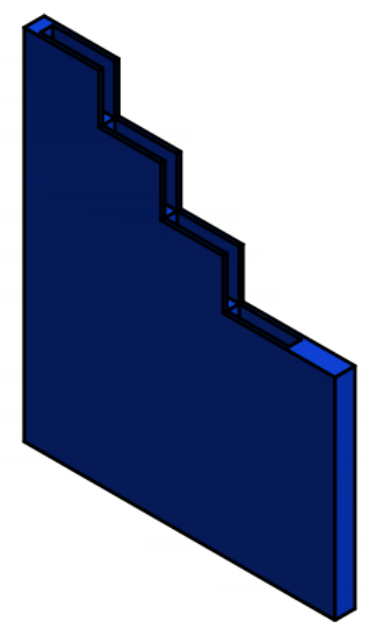

Fig 6. Radiator

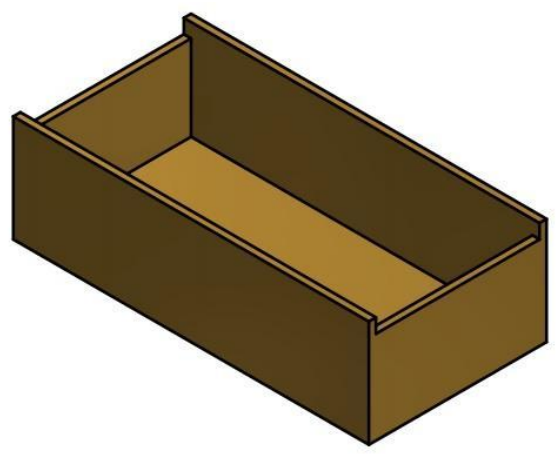

Fig 7. Colling Tank

The heat carried by the coolant will gradually disappear because it is wasted by insulators on the aluminum in the reservoir tank, radiator, and colling tank. Afterward, coolant liquid is pumped back to the colling tank using the 3-volt pump. This mechanism results in maximum cooling of the TEC-12706 Peltier side.

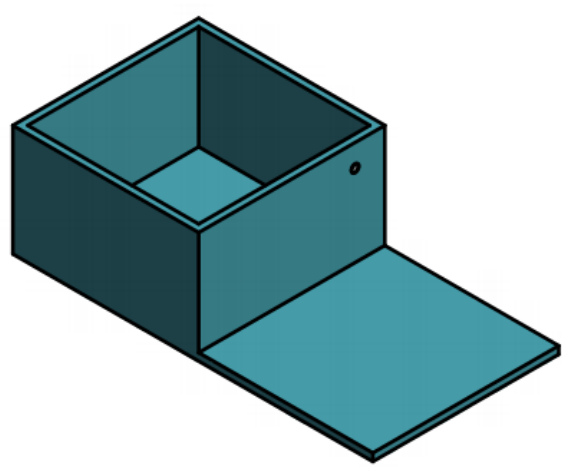

Fig 8. Reservoir Tank

The design that has been made as a smart stove is then realized in the developed prototype. The predominance of aluminum is chosen so that heat energy can be maximally funneled. The smart stove frame uses an iron plate with a thickness of $3 \mathrm{~mm}$ to support the cookware firmly and durable. The overall design of the prototype of the electric smart stove is shown in Figure 9. 


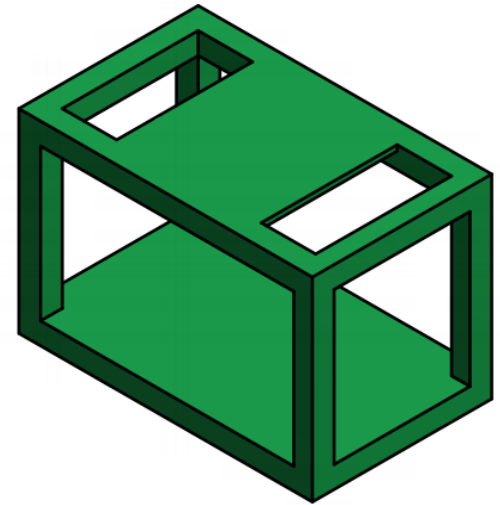

Fig 9. Electric Smart Stove Prototype Frame

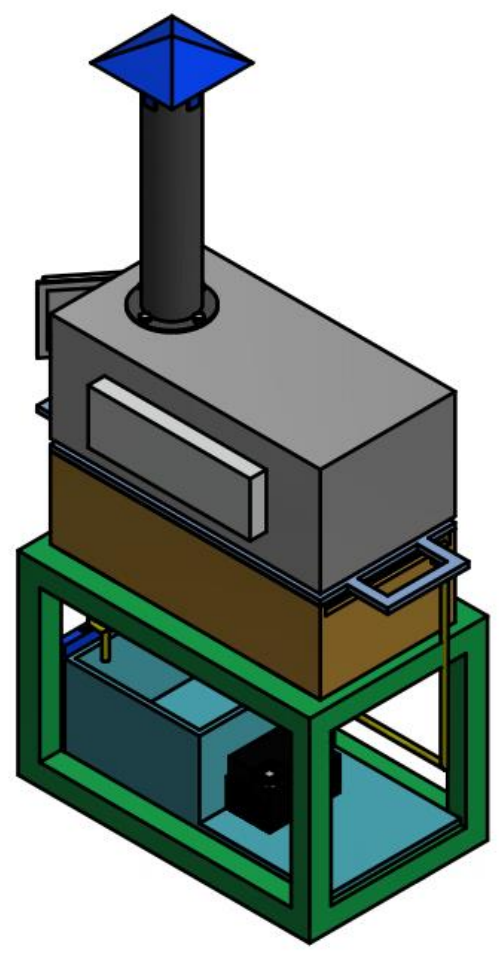

Fig 10. Electric Smart Stove Prototype Design

B. Output Electrical Power prototype of the electric smart stove

The prototype design of the electric smart stove is designed by utilizing heat from the stove and then converting it into electrical energy. The thermoelectric generator used is the Peltier TEC-12706. The thermoelectric generator is placed under the combustion medium so that the thermoelectric generator receives maximum heat.

Thermoelectric generators work based on the difference in temperature between the two sides. The greater temperature difference (delta $\mathrm{T}$ ) will produce greater electrical energy. The generation of electrical energy with a temperature difference phenomenon is called the Seebeck effect.

The fuel used in testing the prototype of an electric smart stove is Tectona grandis briquettes from teak leaf waste. The choice of fuel from briquettes because it produces a calorific value that can compete with firewood. Load the prototype of an electric smart stove using a pot filled with water.
Testing the electrical energy output generated by the prototype of an electric smart stove using a voltmeter and an ammeter electric measuring instrument. Meanwhile, to measure the temperature on the Thermosplate using a laser thermometer. The temperature measurement is carried out on the outer side of the thermosplate. This is done because the part of the thermosplate that can be measured is only the outer side. While the middle side of the thermosplate is blocked by the briquette combustion chamber and radiator. Measurement of the temperature on the outside of the thermosplate is expected to represent the temperature of the thermosplate. Data retrieval of electrical power output and temperature on the prototype of an electric smart stove is carried out every 10 minutes. Table 1 shows the measurement data on the Smart Stove prototype.

Table 2. Data Results of Measurement Electric Power Output Smart Stove Prototype

\begin{tabular}{|c|c|c|c|c|c|c|}
\hline \multirow[t]{2}{*}{ No. } & \multirow{2}{*}{$\begin{array}{l}\text { Tim } \\
\text { e } \\
\text { (mi } \\
\text { nute } \\
\text { ) }\end{array}$} & \multirow{2}{*}{$\begin{array}{l}\text { Thermo } \\
\text { splate } \\
\text { temper } \\
\text { ature } \\
\text { (C) }\end{array}$} & \multicolumn{2}{|c|}{$\begin{array}{l}\text { Thermoelect } \\
\text { ric generator } \\
\text { temperature } \\
\text { (C) }\end{array}$} & \multirow{2}{*}{$\begin{array}{c}\Delta \mathrm{T} \\
\text { Thermo } \\
\text { electric } \\
\text { generat } \\
\text { or }\end{array}$} & \multirow{2}{*}{$\begin{array}{c}\text { Thermo } \\
\text { electric } \\
\text { generat } \\
\text { or } \\
\text { output } \\
\text { (Volt) }\end{array}$} \\
\hline & & & $\begin{array}{l}\text { Hot } \\
\text { side }\end{array}$ & $\begin{array}{l}\text { Cold } \\
\text { side }\end{array}$ & & \\
\hline 1 & 0 & 2 & 31 & 31 & 0 & 0 \\
\hline 2 & 10 & 2 & 53 & 40 & 13 & 0.56 \\
\hline 3 & 20 & 132 & 85 & 45 & 40 & 1.31 \\
\hline 4 & 30 & 135 & 87 & 48 & 39 & 1.27 \\
\hline 5 & 40 & 137 & 88 & 50 & 38 & 1.24 \\
\hline
\end{tabular}

Table 2 is the result of measuring the parameters on the smart stove prototype. The measurement results show that the highest delta T occurs in the 20th minute, namely 40 degrees Celsius. After 20 minutes, the second $\mathrm{T}$ is gradually decreasing, although not significant. This shows that the effectiveness of the energy absorbed occurs until the 20th minute.

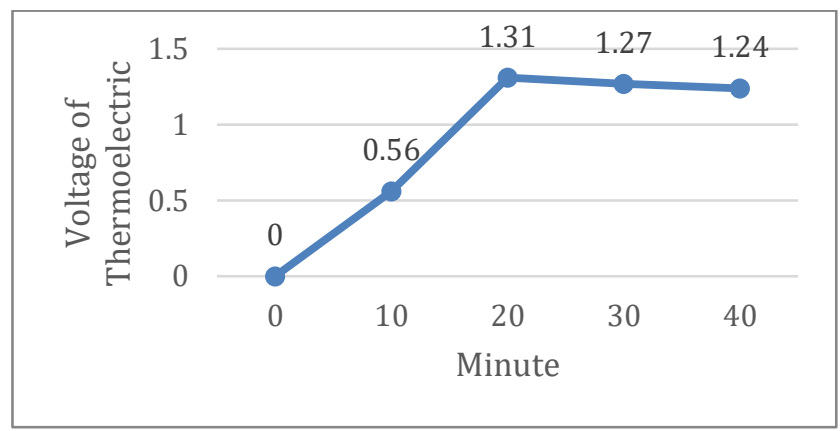

Fig. 11. The output voltage of the thermoelectric generator

Figure 11 shows the output voltage of the thermoelectric generator. Thermoelectric generators produce the highest voltage in the 20th minute with a voltage value of 1.31 volts with delta T 40 degrees Celsius. After 20 minutes the thermoelectric output voltage continues to decrease. The decrease is accompanied by a decrease in delta $\mathrm{T}$. The delta value affects the thermoelectric generator voltage output, because the greater the delta $\mathrm{T}$ value, the greater the voltage output from the thermoelectric. 


\section{CONCLUSION}

Based on the results of research that has been done, it can be concluded:

1. The prototype of an electric smart stove can generate electrical energy by utilizing the temperature difference in the Peltier module TEC-12706. Peltier modules are used as many as 12 units. The maximum voltage output obtained is 1.31 volts with a delta $\mathrm{T}$ of 40 degrees Celsius.

2. The temperature difference from the hot and cold sides of the TEC-12706 Peltier module greatly affects the thermoelectric voltage output of the generator, so the placement of the Peltier module on the prototype of an electric smart stove needs to be considered so that the absorption of heat energy can be maximized.

3. The electrical energy generated by the prototype of an electric smart stove has not been able to charge the battery. This is because the resulting voltage output is small and insufficient for filling the battery.

\section{REFERENCES}

[1] Mulayani. D,. Hartono. D., (2018). Pengaruh Efisiensi Energi Listrik pada Sektor Industri dan Komersial terhadap Permintaan Listrik di Indonesia. Jurnal Ekonomi Kuantitatif TerapanVol 11 No.1. pISSN : 2301 8968 eISSN : $2303-0186$

[2] Sa'adah. A. F., et al. (2017). Prediction of Fuel Supply and Consumption in Indonesia with System Dynamics Model. Jurnal Ekonomi dan Pembangunan Indonesia Vol. 17 No. 2 Januari 2017: 118-137 p-ISSN 1411-5212; e-ISSN 2406-9280.

[3] Maslamani M. T., et al. (2014). Development of Solar Thermoelectric Generator. European Scientific Journal March 2014 edition, vol.10, No.9 ISSN: 1857 - 7881 (Print) e - ISSN 1857- 7431

[4] F. Keith dan A. Priyono. 1998. Prinsip-prinsip Perpindahan Panas, Edisi ke-3. Jakarta: Erlangga

[5] Rosyidi. F., M., et al. (2020). Rancang bangun kompor biomassa penghasil energi listrik untuk mengisi baterai $12 \mathrm{~V}$. Teknika: Jurnal Sains dan Teknologi. Vol 16 No 02. 279-284

[6] Nandy P., et al. (2009). Potensi Pembangkit Daya Termoelektrik untuk Kendaraan Hybrid. MAKARA. TEKNOLOGI. VOL. 13. No. 2. November 2009: 53-58

[7] Cekdin C., Nawawi Z., Faizal M. (2020). The usage of thermoelectric generator as a renewable energy source. TELKOMNIKA Vol. 18, No. 4, August 2020, pp. 2186-2192.

[8] Sugiyanto, et al. (2014). Pemanfaatan panas pada kompor gas LPG untuk pembangkitan energi listrik menggunakan generator thermoelektrik. Jurnal Teknologi, Volume 7 Nomor 2, Desember 2014, 100 105 